\title{
$\mathrm{ABO}$ and Rh Blood Group Distribution in Kayseri Province, Turkey
}

\author{
Kayseri İlinde $A B O$ ve Rh Kan Grupları Dağılımı
}

\author{
Yasemin Altuner Torun ${ }^{1}$, Leyla Gül Kaynar², Çigdem Karakükcü ${ }^{3}$, Mehmet Yay $^{2}$, \\ Fatih Kurnaz ${ }^{2}$, Hasan Mutlu ${ }^{1}$, Mustafa Çetin ${ }^{2}$, Bülent Eser ${ }^{2}$ \\ ${ }^{1}$ State Educational and Research Hospital, Transfusion Center, Kayseri, Turkey \\ ${ }^{2}$ Erciyes University, School of Medicine, Department of Hematology, Kayseri, Turkey \\ ${ }^{3}$ State Educational and Research Hospital, Department of Biochemistry, Kayseri, Turkey
}

\section{To the Editor,}

Today, there are more than 600 antigenic structures among the 30 defined blood groups [1]. The ABO system was first described by Landsteiner in 1900, and remains the most important in the management of tissue and blood transfusion. Indeed, the Rh system has the most important antigen D structure and is the most widely used prior to transfusion [1,2].

It has been shown that the frequency of $\mathrm{ABO}$ blood groups differs between populations [1,3]. Determination of the frequency of blood groups in a particular region facilitates timely provision of blood and blood products. There are many studies on the distribution of blood groups in Turkey [4-10]; however, none have considered Kayseri Province, a densely populated city in central Anatolia. As such, the present study aimed to determine the frequency of blood group types in Kayseri Province in order to facilitate to reach the appropriate blood type .

Blood samples obtained from 86,797 individuals that presented to blood banks run by Erciyes University, School of Medicine, State Educational and Research Hospital, between January 2008 and September 2010 were retrospectively analyzed. $\mathrm{ABO}$ group types and Rh specificity of the blood samples were determined using a DiaMed-ID Micro Typing System (DiaMed AG, Switzerland) via gel centrifugation. Among the participants,
45,134 (52\%) were female and 41,663 (48\%) were male. In all, $88.2 \%$ ( $\mathrm{n}=76,580)$ of the blood samples were Rhpositive and $11.8 \%(\mathrm{n}=10,217)$ were $\mathrm{Rh}$ negative. The frequency of A, O, B, and AB blood group types was 44\% $(n=38,253), 33.3 \%(n=28,904), 16.2 \%(n=14,031)$ and $6.5 \%(n=5609)$, respectively. The frequency of ABO and $\mathrm{Rh}$ blood groups is shown in Figure 1.

ABO blood groups are determined based on a locus on chromosome 93/4the Rh gene is on the first chromosome [1]. The Rh system is clinically as important as the ABO system because of its role in hemolytic diseases in newborns and in transfusion incompatibility [1]. ABO and Rh blood groups usually exhibit ethnic and regional differences $[1,3]$. The present findings show that the frequency of $A$, $\mathrm{B}, \mathrm{O}$, and $\mathrm{AB}$ blood group types in Kayseri is in accordance with that in the general Turkish population.

In total, $44 \%$ of the blood samples analyzed in the present study were blood group A, which is similar to the frequency in other central Anatolian cities, including Konya, Eskişehir, and Ankara [4-6]. The frequency of the O blood group in Turkey is reported to be between $30.8 \%$ and $41.2 \%$. In the present study the frequency of the O blood group was $33.3 \%$, which is the same as in the Turkish cities Denizli and Diyarbakır [7,8], and the frequency of the B type blood group in the present study was $16.2 \%$, which is similar to that in Eskişehir

Address for Correspondence: Yasemin ALTUNER TORUN, M.D.,

Kayseri Eğitim ve Araştırma Hastanesi, Transfüzyon Merkezi, Kayseri, Turkey

Phone: +90 5339385282 E-mail: yaseminaltuner@yahoo.com

Received/Geliş tarihi : May 5, 2011

Accepted/Kabul tarihi : August 26, 2011 
and Denizli $[4,7]$. In Turkey the highest frequency of the B blood group is in Sanlurfa (21.25\%) and the lowest frequency is in Malatya (11.4\%) [9]. The AB blood group has a frequency in Turkey of 6\%-9.2\%, which is similar to the $6.5 \%$ observed in the present study.

The frequency of Rh-negative individuals varies enormously between ethnic groups. For example, 17\% of Brits are Rh negative, versus $0.5 \%$ of Japanese; ${ }^{3}$ however, the frequency of Rh negative in Turkey is nearly $15 \%$, which is similar to that in Asia and Europe [1,2]. In the present study the Rh positivity rate was $88.2 \%$, whereas other studies conducted in Turkey reported that the Rh positivity rate was $90.8 \%$ in Gaziantep, $89 \%$ in Malatya, 89.1\% in Diyarbakır, and 89.9\% in Denizli [8-10].

In conclusion, the frequency of the $\mathrm{ABO}$ and Rh blood groups observed in Kayseri Province in the present study differs from that in other Turkish cities, but is similar to that in the general Turkish population. This could be due to the fact that Kayseri Province is located in the center of Turkey. In recent years Kayseri has experienced the influx of a high number or migrants coming from other regions of Turkey (especially the south and east) due an increase in the number of industrial jobs. According to Turkish nationwide population statistics (Türkiye İstatistik Kurumu) for 2008-2009, 28,831 people migrated to Kayseri3/4a migration rate of $1.86 \%$. It is critically important that blood banks know the distribution of blood group types in their region. We think that the present study's findings, as those from studies conducted in other Turkish cities, will contribute to the Turkish blood type database and, most importantly, will facilitate easy access to appropriate blood types, as needed.

\section{References}

1. Lialiaris T, Digkas E, Kareli D, Pouliliou S, Asimakopoulos B, Pagonopoulou O, Simopoulou M: Distribution of $\mathrm{ABO}$ and Rh blood groups in Greece: An update. Int J Immunogenet 2011; 38: 1-5

2. Daniels GL, Cartron JP, Fletcher A, Garratty G, Henry S, Jørgensen J, Judd WJ, Levene C, Lin M, Lomas-Francis C, Moulds JJ, Moulds JM, Moulds M, Overbeeke M, Reid ME, Rouger P, Scott M, Sistonen P, Smart E, Tani Y, Wendel $\mathrm{S}$, Zelinski T: International Society of Blood Transfusion Committee on terminology for red cell surface antigens: Vancouver Report. Vox Sang 2003; 84:244-247

3. Akbay T, Demiröz P, Güney C: Türkiyede kan gruplarının coğrafi bölgelere göre dagilımı. GATA Bült 1989; 31: 391-402

4. Dilek İ, Demir C, Bay A,Akdeniz H, Öner AF: ABO and Rh blood groups frequency in men and women living in eastern Turkey. UHOD 2006; 1: 23-26

5. Demirağ N, Öz AY, Akın M: Blood groups distribution of Konya city and comparison to Turkey and Estern Cyprus. İç Anadolu Tıp Dergisi 1993; 3: 68-71

6. Ergin A, Yardimci S: Distribution of $\mathrm{ABO}$ and Rh blood groups in Turkey. Ankara Üni Tip Fak Mec 1993; 46: 527-533

7. Isık Balcı Y, Ovet G, Covut IE, Goncu F, Yilmaz F: ABO and Rh Blood Groups Frequency in Denizli Province. UHOD 2010; 20: 103-105

8. Temiz H, Altıntaş A, Gül K: Distrubition of ABO and Rh Blood Groups in Diyarbakır. UHOD 2008; 4: 235-237

9. Yakıncı C, Durmaz Y, Şahin: Malatya Yöresinde ABO ve Rh Kan Gruplarının Dağılımı. Turgut Özal Tıp Merkezi Dergisi 1995; 2: 277-279

10. Coşkun Y: "ABO" "Rh" distribution of blood groups in Gaziantep region. Gaziantep Üniversitesi Tıp Fakültesi Dergisi 1990; 1: 13-18 